\title{
AML 型人工股関節置換術の中期成績
}

\author{
山口大学医学部整形外科 \\ 大野晃靖・城 戸研二 \\ 田中浩・脇 坂 敦 彦 \\ 大井律子・河合伸也
}

\section{Mid-term Results of Anatomic Medullary Locking Total Hip Arthroplasty}

\author{
Teruyasu Ohno, Kenji Kido, Hiroshi Tanaka, \\ Atsuhiko Wakisaka, Ritsuko Ohi, and Shinya Kawai \\ Department of Orthopedic Surgery, School of Medicine, Yamaguchi University Ube, Japan
}

\begin{abstract}
The results of thirty-one consecutive primary total hip arthroplasties using the anatomic locking hip system were reviewed after a minimum of five years. Their pre-operative JOA score of 41 points improved to 88 points post-operatively. One performed revision surgery. The survival rate at five years from the operation was 0.97 . Proximal femoral bone atrophy appeared in twentyfive hips (83\%), but the revision case showed no bone atrophy. It is not clear whether the proximal femoral bone atrophy correlated with the stability of the femoral component. The cementing technique in the revised case was grade $\mathrm{C}$. We considered this was the most important cause for loosening. The width of the clear zone of another two hips showed more than $2 \mathrm{~mm}$. These two cases finally showed stem loosening, but did not undergo surgery.
\end{abstract}

Key words : Total Hip Arthroplasty (人工股関節置換術), Anatomic Medullary Locking system (AML 型), survival rate (生存率)

\section{はじめに}

今回，当科で施行した AML 型人工股関節の中期成 績について報告する．

\section{対象 ・ 方 法}

当科で行った $\mathrm{AML}$ 型人工股関節置換術のうち経過 観察期間が 5 年以上 行うことができた 28 例 31 関節, 男 7 例 8 関節，女 21 例 22 関節を対象とした。経過観 察期間は平均 7.1 年 ( 5 年 8.2 年), 手術時平均年齢 は 59 歳 (44 77 歳), 対象疾患は変形性関節症 28 関 節（うち 1 例は再置換例)，関節リウマチ 2 関節，大 腿骨頭壊死 1 関節であった．検討項目は術前術後の日 整会股関節評価点数, 以下 JOA score を用い 臨床評
価を行った．X線学的評価は大腿骨側の cementing technique の 程度, clear zone, 大腿骨近位部の骨 萎縮, 骨硬化の有無について検討を行った. Cementing techniqueはAからDの 4 段階に分類した。 Clear zone は Amstutz ${ }^{1)}$ の分類に沿って7 個の zoneに分け，また，その staging を長屋ら ${ }^{6)}$ の分類 に沿って $5 つ に$ staging を行った. 大腿骨骨萎縮の 程度の分類は stress shieldingについて Engh ら ${ }^{2)}$ が 報告したものに従い分類した。

$$
\text { 結果 }
$$

JOA score は術前平均 40 点が術後 5 年で 97 点と 改善していた，項目別にもすべてに渡り改善してい た. 術後に出現した症状においては, 疼痛を 4 例に認 
めた。 そのうち 2 例は一時期のみで, 疼痛発生時の X 線写真む, 特に変化は認められなかったが, 再置換術 となったものが 1 例, loosening があるあのの経過観 察中のあのが 1 例であった。 clear zone は cementless に 8 関節，73\%，cemented では 11 関節 $55 \%$ に認められ, cementless では stage 1 が 6 関 節, stage 2 が 2 関節であった.

一方， cemented は stage 1 が 4 関節， stage 2 は 4 関節， stage 3 は 2 関節， stage 4 は 1 関節であっ た. cementedのうち, stage 4 であった 1 関節は術 後 7 年目で再置換術となった. cementing technique は grade A 9 関節 (45\%)，Bは6 関節 (30\%)，C は 5 関節（25\%）であった。 また，それぞれの clear zone は grade A に， 2 関節 (22\%)，Bに 5 関節 (83 \%)，Cに 4 関節（80\%）に認められ，grade A が もっとも出現率が低加た， cementedに扔いて initial gap は 7 関節ありすべて $1 \mathrm{~mm}$ 以下であった. 5 年後には clear zone として認め, 2 関節が $1 \mathrm{~mm}$ 以上となった． stem 周囲に出来た骨硬化像は 5 例 （46\%）に認められたが，すべて porous coatingさ れていない部分であった，大腿骨近位部の骨萎縮は mild が 15 関節，moderate が 9 関節， severe は 1 関 節に認め, 平均年齢は，それぞれ 60 歳， 62 歳， 74 歳 であり，比較的高年齢者に多かったままた，骨萎縮を 認められなかった zone の症例に sinking を認め, 骨
萎縮の発生は必ずしも stem の固定性の低下を表して いるあのではなかった。

\section{症例（再置換例）}

70 歳男性. 变形性股関節症.

術後 5 年目までは特に症状むなく, JOA score 98 点, 屈曲 100 度之可動域の減点のみであったが, その 直後より thigh pain を訴え, X線写真であ徐々に 2 $\mathrm{mm}$ 以上の clear zone と sinking を認め, 今回の症 例中 唯一の再置換の症例之なった（図 1). 拔去され た stem の尖端の porous coating が行われていない 部分のみ欠損しており，その他の部分は強固に cement が付着していた（図 2 )。この症例の cementing technique は grade C であり cementによる固 定性に問題があったと考えている.

\section{考察}

cementless と hybrid の JOA score はそれぞ れ 45 点，38点と hybrid の方が低くなっている．これはそ れぞれの平均年齢は 56 歳, 62 歳とやや, hybrid の 方が高くなっており，このために JOA scoreが hybrid の方で低くなっていると考えた。

stem 側の再置換を endpoint とした生存率では Engh ら ${ }^{3)}$ の報告をはじめとして 96 98\% ${ }^{43}$ 5) と良 好な成績が得られており，当科であ約 $97 \%$ と同等な

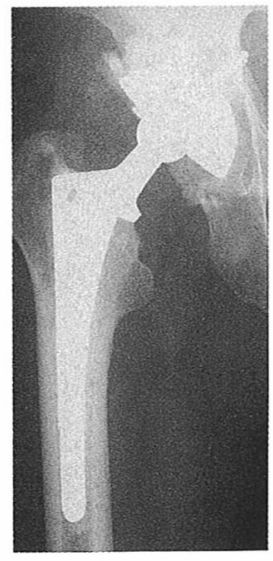

術後

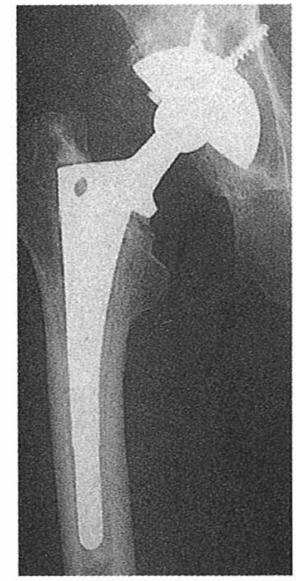

術後 5 年

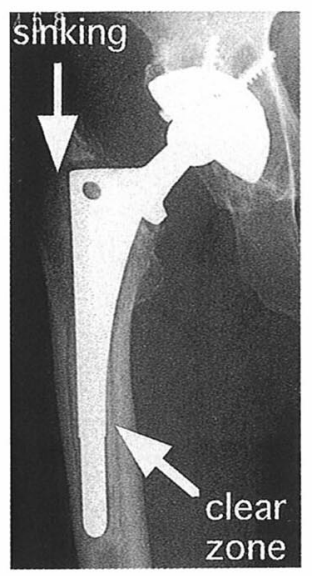

術後 7 年

図 1 症例 70 歳 男性 変形性関節症

特に症状むなく, JOA score 98 点, X-p も良好であったが, 術後 5 年にthigh pain を訴え, X-p でもclear zone と sinking を認め, JOA score 29 点となり, 術後 7 年目で再置換術を行った. 


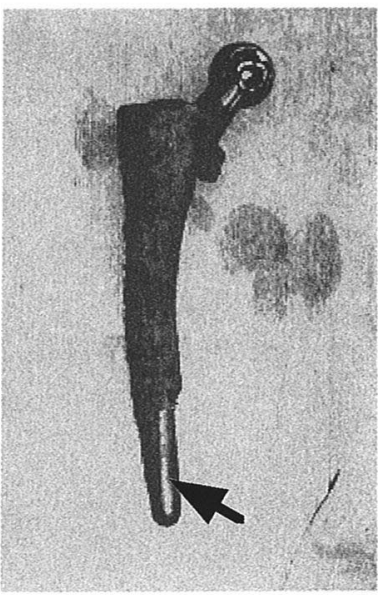

a

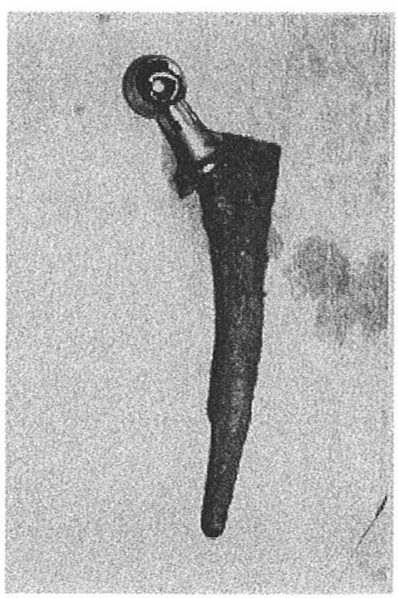

b

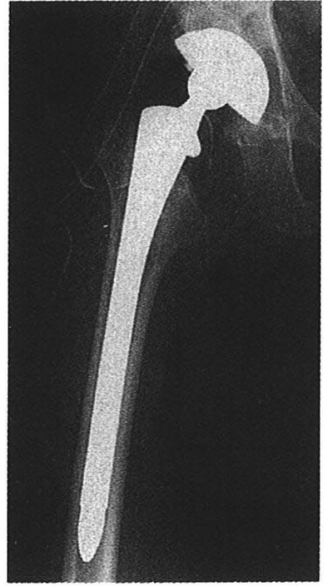

c

図 2 術後 7 年目に再置換術を行った際に拔去された stem である. a において stem 先端のみが cement が欠損し ており，この部位 (矢印) は porous coating されていない部分であった。 c は再置換術後のX-pである.

成績が得られた.

広範囲に porous coating が施されている AML 型 人工 股関節においては stress shielding による骨萎 縮が問題とされ，骨折や大腿部痛の発生が危惧されて いる. しかし, Engh ${ }^{2)}$ や小幡ら ${ }^{7)}$ は stress shielding は bone-ingrowth fixation の完成により発生するむ ので, 特に, 合併症はなかったと報告している. 我々 の症例では固定方法によらず骨萎縮を認めたが, 合併 症はなかった。

Clear zone に関しては $1 \mathrm{~mm}$ 以下のものは Golding らが示すように安定した固定を示し， $2 \mathrm{~mm}$ 以上のむのは不安定性を有し, 経過観察に注意を要す る. また, cementless でみられた骨硬化像はその部 分にかかる応力によるものとされるが，今回骨硬化像 が認められた症例は, porous coating が行われてい ない尖端のみで特に問題にはならないと考えた。

(1)AML 型人工股関節置換術 28 例 31 関節の中期成績 について検討を行った。

(2)JOA score は術前 41 点から術後 5 年で 88 点と改 善しており再置換例は 1 症例のみと良好な成績が得ら れた。

(3)骨菱縮の発生は必ずしも stem の固定性の低下を反
映してはいなかった。

(4)clear zone は $1 \mathrm{~mm}$ 以下であれば経過良好であっ た.

\section{参 考 文 献}

1) Amstutz. H. C. : Complications of total hip replacement. Clin. Orthop. $72: 123-137$

2) Engh CA : The influence of stem size and extent of porous coating on femoral bone resorption after primary cementless hip arthroplasty. Clin. Orthop., 231 : 7-28. 1988.

3) Engh CA Jr. : Long-term results of use of the anatomic medullary locking prosthesis in total hip arthroplasty. J Bone Joint Surg Am, 79 : 177-184, 1997.

4) Kim YH : Cementless porous-coated anatomic medullary locking total hip prostheses. J Arthroplasty, $9:$ 243-252, 1994.

5) Krishnamurthy AB. : 5-to 13-year follow-up study on cementless femoral components in revision surgery. J Arthroplasty, $12: 839-847,1997$.

6）長屋郁郎，：全人工股関節置換術（Muller）の検討. 日整会誌，47：1223-1225， 1973.

7）小幡浩之ら：AML型セメントレスステムにおける stress shielding の解析. 関節外科, $15: 1416-1420$, 1996. 